\title{
MEMPREDIKSI USIA DAN JENIS KELAMIN MENGGUNAKAN CONVOLUTIONAL NEURAL NETWORKS
}

\author{
Afrizal Zein ${ }^{1}$ \\ Program Studi Teknik Informatika, STMIK Eresha \\ Jl. Raya Puspitek Serpong No. 10 Tangerang Selatan Banten \\ Email: zeinafrizal@gmail.com
}

\begin{abstract}
The main objective of this study was to develop a method for estimating the age and gender of a person based on facial images, using CNN in-depth training that can accurately recognize age and gender. Information that is extracted can be useful in, for example, security or commercial applications. This is a difficult estimation problem, because the only information we have is a picture, that is the look of that person.

The next aspect of this study I focused on incorporating architecture for age and gender recognition to take advantage of gender-specific age characteristics and age-specific gender characteristics inherent in the image. This comes from the observation that sex classifications are tasks that are inherently easier than age classifications, because both fewer and fewer potential classes and more prominent intra-gender facial variations. With the training of different age classifiers for each gender I found that I could improve the performance of age classifications, even though gender classification did not see significant results.
\end{abstract}

Keywords: Age + Gender Recognition, Convolutional Neural Networks, Prediction

\begin{abstract}
Abstrak
Tujuan utama dari penelitian ini adalah untuk mengembangkan metode untuk memperkirakan usia dan jenis kelamin seseorang berdasarkan gambar wajah, menggunakan pelatihan mendalam CNN yang dapat secara akurat mengenali usia dan jenis kelamin. Informasi yang diekstraksi dapat berguna dalam, misalnya, keamanan atau aplikasi komersial. Ini adalah masalah estimasi yang sulit, karena satu-satunya informasi yang kami miliki adalah gambar, itulah tampilan orang itu.

Aspek selanjutnya dari penelitian ini saya fokus pada penggabungan arsitektur untuk usia dan pengenalan gender untuk mengambil keuntungan dari karakteristik usia spesifik gender dan karakteristik gender spesifik usia yang melekat dalam gambar. Ini berasal dari pengamatan bahwa klasifikasi jenis kelamin adalah tugas-tugas yang secara inheren lebih mudah daripada klasifikasi usia, karena semakin sedikit kelas potensial dan variasi wajah intra-gender yang lebih menonjol. Dengan pelatihan pengklasifikasi usia yang berbeda untuk setiap jenis kelamin saya menemukan bahwa saya dapat meningkatkan kinerja klasifikasi usia, meskipun klasifikasi gender tidak melihat hasil yang signifikan.
\end{abstract}


Kata kunci : Usia + Pengenalan Gender, Jaringan Syaraf Konvolusional, Prediksi

\section{Pendahuluan}

Beberapa klasifikasi paling mendasar mengenai manusia adalah usia dan jenis kelamin. Mereka ada di antara hal pertama yang diputuskan saat melihat seseorang. Keputusan ini didasarkan pada banyak hal fitur yang berbeda dan benar-benar datang dari orang tersebut, tetapi juga dari lingkungan. Bagian pemasaran atau penjualan perusahaan biasanya tertarik dengan produk mereka terhadap pelanggan yang ditargetkan. Jadi, penting di banyak bidang untuk memiliki statistik target audiens produk mereka. Dengan cara yang sama, beberapa layanan, perizinan atau produk hanya diizinkan untuk pemirsa jenis kelamin atau usia tertentu, dan itu harus dikendalikan entah bagaimana caranya.

Menyatukan dua gagasan yang disebutkan di atas, kebutuhan untuk memperkirakan jenis kelamin dan usia dalam beberapa cara otomatis muncul. Manusia dapat dengan mudah membuat perkiraan ini dari wajah. Namun, itu masih merupakan tugas yang menantang untuk komputer. Proyek ini difokuskan pada usia dan jenis kelamin untuk memprediksi berdasarkan gambar wajah menggunakan teknik visi komputer. Tujuan dari proyek ini bukan untuk menciptakan sistem prediksi, tetapi untuk mengembangkan metode prediksi dan akhirnya membuat prototipe sistem menggunakan metode tersebut.

Meskipun prototipe sistem diharapkan dapat bekerja hampir sebaik manusia lakukan, itu memiliki beberapa keterbatasan. Seperti yang kami katakan, ada banyak informasi yang digunakan oleh manusia memperkirakan usia atau jenis kelamin, secara sadar atau tidak sadar, seperti suara, pakaian, perilaku. Sehingga sulit untuk mencapai kinerja seperti sebaik manusia. Bahkan hanya dengan gambar wajah, manusia akan menggunakan beberapa informasi tingkat tinggi, seperti warna kulit, gaya rambut, rambut wajah yang dapat menjadi sulit untuk sistem prototype untuk mengekstraknya. Di sisi lain sistem akan menggunakan teknik penglihatan komputer yang manusia tidak bisa digunakan. Karena proyek ini memiliki banyak aplikasi, dan setiap aplikasi memiliki karakteristik spesifiknya sendiri, kita tidak bisa fokus pada kesalahan akhir dari prediksi yang dihasilkan. Dengan demikian, kami akan mencoba mencari trade-off antara kesalahan dan kompleksitas komputasional, mengambil fitur yang memberikan kinerja yang lebih baik.

Untuk melatih sistem prototipe, database gambar wajah diberi label dengan usia dan jender dibutuhkan. Database ini harus representatif untuk gambar input nyata dari sistem. Karena kita tidak harus membuat aplikasi apa pun tetapi hanya mengembangkan sistem, kita lakukan tidak perlu mencari database yang sangat spesifik.

Langkah-langkah dari setiap proses prediksi adalah: Preprocessing, ekstraksi fitur, estimasi,

dan evaluasi. Langkah preprocessing didefinisikan untuk menyiapkan data untuk fitur tersebut

langkah ekstraksi. Metode ini bekerja di tingkat piksel (gradien), di tingkat objek atau level gambar (crop dan rotasi). Gambar juga diubah menjadi grayscale dan diubah ukurannya menjadi ukuran tetap sehingga semuanya memiliki jumlah fitur yang sama. 
Untuk mengembangkan sistem prototipe, diperlukan dua jenis fitur: tingkat tinggi dan fitur tingkat rendah. Fitur tingkat tinggi adalah mereka yang memiliki koneksi langsung dengan usia dan jenis kelamin, seperti kehadiran rambut, kumis, janggut atau kerutan. Di sisi lain, itu fitur tingkat rendah tidak memiliki korelasi visual yang jelas dengan prediksi dan mereka diekstraksi menggunakan teknik penglihatan komputer yang paling umum, seperti gradien, hessian, perbedaan pixel atau Histogram of Oriented Gradients (HOGs). Untuk mengekstraksinya, kita perlu beberapa pengetahuan tentang di mana beberapa keypoints wajah berada, maka semacam pelacakan Algoritma diperlukan.

Ada perbedaan penting antara usia dan jenis kelamin: untuk jenis kelamin, ada dua yang jelas kelas-kelas yang berbeda (laki-laki dan perempuan), sedangkan untuk prediksi usia, nilai-nilai yang diprediksi adalah terus menerus, sehingga metode estimasi harus berbeda. Untuk alasan ini, jenis kelamin adalah diperkirakan dengan metode klasifikasi dan usia dengan metode regresi. Metode Deep Learning yang saat ini memiliki hasil paling signifikan dalam pengenalan wajah adalah Convolutional Neural Network (CNN) [4]. Hal tersebut dikarenakan CNN berusaha meniru sistem pengenalan wajah pada visual cortex manusia [5] sehingga memiliki kemampuan mengolah informasi citra. Namun CNN, seperti metode Deep Learning lainnya, memiliki kelemahan yaitu proses pelatihan model yang lama. Dengan perkembangan perangkat keras, hal tersebut dapat diatasi menggunakan teknologi General Purpose Graphical Processing Unit (GPGPU).

\section{Tinjauan Pustaka}

Menurut penelitian yang dilakukan oleh ( I Wayan Suartika E. P, Arya Yudhi Wijaya, dan Rully Soelaiman, 2016) yang berjudul "Klasifikasi Citra Menggunakan Convolutional Neural Network (Cnn) pada Caltech 101" menjelaskan bahwa Dengan mengimplementasikan salah satu metode machine learning yang dapat digunakan untuk klasifikasi citra objek yaitu CNN. Metode CNN terdiri dari dua tahap. Tahap pertama adalah klasifikasi citra menggunakan feedforward. Tahap kedua merupakan tahap pembelajaran dengan metode backpropagation. Sebelum dilakukan klasifikasi, terlebih dahulu dilakukan praproses dengan metode wrapping dan cropping untuk memfokuskan objek yang akan diklasifikasi. Selanjutnya dilakukan training menggunakan metode feedforward dan backpropagation.

Menurut penelitian yang dilakukan oleh ( Thakshila R. Kalansuriya and Anuja T. Dharmaratne, 2014) Identifikasi wajah otomatis dan verifikasi dari gambar wajah mencapai akurasi yang baik dengan set data pelatihan yang besar sementara pengenalan atribut wajah dari gambar wajah masih tetap menantang. Oleh karena itu memperkenalkan klasifikasi citra wajah yang efisien dan akurat berdasarkan atribut wajah adalah tugas yang penting. Makalah ini mengusulkan metodologi untuk usia dan jenis kelamin klasifikasi otomatis berdasarkan ekstraksi fitur dari gambar wajah. Berbeda dengan mekanisme lain yang diusulkan dalam literatur, perhatian utama dari metodologi ini adalah penggunaan variasi fitur biometrik pria dan wanita untuk klasifikasi. Ini menggunakan dua jenis fitur yaitu, fitur primer dan sekunder dan itu mencakup tiga iterasi utama: Preprocessing, Ekstraksi fitur dan Klasifikasi. Penelitian ini telah dilakukan menggunakan gambar wajah rentang usia 8-60 tahun yang terdiri dari kedua jenis kelamin dan klasifikasi usia telah dilakukan sesuai dengan rentang usia yang telah ditetapkan. Solusi yang diusulkan mampu mengklasifikasikan gambar dalam kondisi pencahayaan yang berbeda dan kondisi pencahayaan yang berbeda. Klasifikasi dilakukan menggunakan Jaringan Saraf Tiruan sesuai dengan variasi bentuk dan tekstur yang berbeda dari kerutan pada gambar wajah. Penelitian ini telah dievaluasi dan diuji pada gambar wajah asing dan Asia di kedua jenis kelamin dan empat kategori usia yang digunakan.

Menurut penelitian yang dilakukan oleh ( Ari Ekmekji, 2014), Makalah ini berfokus pada masalah gender dan usia klasifikasi untuk suatu gambar. Saya membangun pekerjaan sebelumnya yang telah 
mengembangkan arsitektur yang akurat dan efisien untuk ini tugas dan bertujuan untuk memperluas pendekatan mereka untuk meningkatkan hasil. Area eksperimen pertama dalam hal ini proyek memodifikasi beberapa arsitektur yang sebelumnya diterbitkan dan efektif digunakan untuk jenis kelamin dan klasifikasi usia. Saya upaya termasuk mengurangi jumlah parameter (dalam gaya), meningkatkan kedalaman jaringan, dan memodifikasi tingkat putus sekolah yang digunakan. Modifikasi ini sebenarnya berakhir menyebabkan kinerja sistem menurun (atau paling baik, tetap sama) dibandingkan dengan arsitektur yang lebih sederhana Saya mulai dengan. Ini membuktikan kecurigaan yang saya miliki tugas usia dan klasifikasi jenis kelamin lebih rentan over-fitting dari jenis klasifikasi lainnya. Aspek berikutnya dari proyek saya berfokus pada penggabungan arsitektur untuk usia dan pengenalan gender untuk mengambil keuntungan karakteristik usia spesifik gender dan usia spesifik karakteristik gender yang melekat pada gambar. Ini berasal dari pengamatan bahwa klasifikasi jenis kelamin adalah tugas yang secara inheren lebih mudah daripada klasifikasi usia, karena keduanya semakin sedikit jumlah kelas potensial dan semakin menonjol variasi wajah intra-gender. Dengan pelatihan yang berbeda pengklasifikasi usia untuk setiap jenis kelamin saya menemukan bahwa saya dapat meningkatkan kinerja klasifikasi usia, meskipun klasifikasi jenis kelamin tidak melihat hasil yang signifikan.

\section{Metode Penelitian}

Tujuan utama, bagaimanapun, adalah bereksperimen dengan pendekatan tingkat tinggi baru untuk menyusun pengklasifikasi ini untuk meningkatkan kinerja. Pengamatan yang saya akukan sejak awal adalah bahwa klasifikasi jenis kelamin adalah tugas yang secara inheren lebih mudah dari klasifikasi usia, baik karena jumlah yang lebih sedikit kelas untuk membedakan antara dan perbedaan yang lebih nyata yang ada di antara jenis kelamin daripada di antara banyak usia elompok. Ini kemudian membawa saya pada kesimpulan bahwa saat itu masuk akal untuk mengasumsikan seseorang harus dapat memastikan someones jender terpisah dari mengetahui usia mereka, atau sebaliknya, ada juga beberapa kemungkinan untuk menggunakan salah satu atribut ini untuk lebih baik menginformasikan prediksi yang lain. Sebagai contoh, jumlah rambut di kepala pria sering bisa menjadi indikator usia yang berguna, tetapi hal yang sama tidak berlaku untuk wanita.

\subsection{Size of Dataset}

Dataset yang digunakan untuk pelatihan dan pengujian untuk proyek ini adalah kumpulan data wajah Adience, yang berasal dari Gambar Wajah Proyek [12] dari Universitas Terbuka Israel (OUI). Ini dataset berisi total 26.580 foto dari 2.284 unik subyek yang dikumpulkan dari Flickr. Setiap gambar dianotasi dengan jenis kelamin dan rentang usia orang tersebut (dari 8 kemungkinanrentang). Gambar tunduk pada berbagai tingkatan oklusi, pencahayaan, dan blur, yang mencerminkan keadaan dunia nyata. Saya menggunakan gambar-gambar yang kebanyakan depan menghadap, yang membatasi jumlah gambar ke sekitar 20.000. Tabel 1 termasuk rincian mengenai distribusi gambar di setiap jenis kelamin dan rentang usia.

.Gambar awalnya berukuran $768 \times 768$, jadi semuanya sudah diproses oleh semua yang diubah ukurannya ke 256x256.

\section{Hasil Dan Pembahasan}

\subsection{System Pelatihan}


Pelatihan dan pengujian untuk proyek ini dilakukan secara eksklusif menggunakan Caffe, berjalan di Amazon EC2 menggunakan tween 1 dan 3 instance sekaligus, masing-masing dengan 1,536 CUDA core dan memori video 4GB.

\begin{tabular}{|c|c|c|c|c|c|c|c|c|c|}
\hline & "0-2 & "4-6 & $8-13$ & $" 15-20$ & "25 - 32 & "38-43 & "48-53 & "60+ & Total \\
\hline Laki-laki & 745 & 928 & 934 & 734 & 2308 & \begin{tabular}{|l|}
1294 \\
\end{tabular} & 392 & 442 & 8192 \\
\hline Perempuan & 682 & 1234 & 1360 & 919 & 2589 & 1056 & 433 & 427 & 9411 \\
\hline Keduanya & 1427 & 2162 & 2294 & 1653 & 4897 & 2350 & 825 & 869 & 1987 \\
\hline
\end{tabular}

Protokol validasi silang subjek-eksklusif 6 kali lipat digunakan untuk memberikan kekuatan tambahan untuk pelatihan, sementara menjaga keandalan hasil. Meskipun banyak dari saya arsitektur jaringan dibangun dari pekerjaan di jaringan saya dilatih dari nol tanpa menggunakan pretrained bobot yang disediakan oleh itu, atau yang lain, proyek. Itu alasan ini harus dilakukan dengan cara saya membagi dataset untuk keperluan proyek saya Langkah pertama yang saya ambil adalah mencoba untuk mereproduksi hasil sebagai dasar karena saya memiliki arsitektur jaringan mereka dan data pelatihan. Saya mencoba untuk meniru eksperimen mereka sedekat mungkin, jadi saya juga menggunakan SGD dengan tingkat pembelajaran 1e-3 yang meluruh dengan faktor 10 setiap 10.000 iterasi dan ukuran batch 50 gambar. Ini terbukti cepat berhasil, dan dalam beberapa jam pelatihan Saya mencapai akurasi yang sangat dekat dengan hasil mereka untuk klasifikasi usia dan jenis kelamin. Hasil ini dicatat pada Tabel 2. Perhatikan bahwa sedikit lebih tinggi kemungkinan karena oversampling mereka lakukan gambar input diikuti dengan mengambil klasifikasi mayoritas dari berbagai sampel. Demi iterasi yang lebih cepat di saya model, saya menghindari teknik ini. 


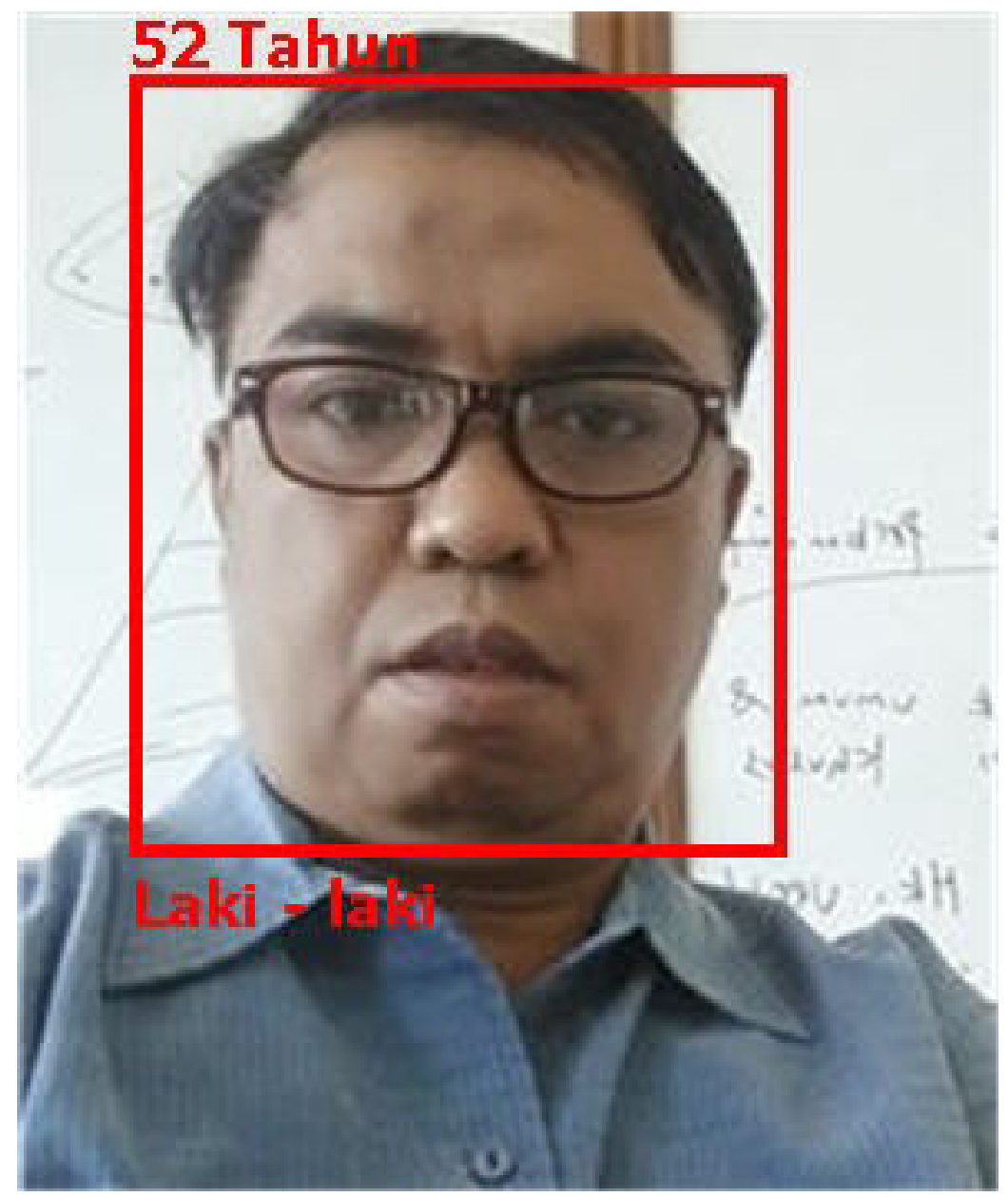

\section{Kesimpulan Dan Saran}

\subsection{Kesimpulan}

Berdasarkan hasil penelitian yang telah dilakukan, maka dapat diambil kesimpulan bahwa pengklasifikasian usia dengan menggunakan metode Convolutional Neural Network (CNN) menghasilkan tingkat akurasi secara keseluruhan sebesar 90\% sedangkan Jenis kelamin mencapai 96\% dengan menggunakan 1000 data pelatihan dan 100 data pengujian.

\subsection{Saran}

Beberapa pekerjaan lebih lanjut berdasarkan proyek itu dapat dilakukan. Informasi warna dari gambar dapat digunakan, serta jenis fitur lainnya seperti eigenfaces. Juga penaksir lainnya dapat diimplementasikan dalam proyek masa depan, misalnya adaptasi SVM untuk regresi.

\section{Daftar Pustaka}

[1] C. Shan,, "Smile detection by boosting pixel differences”, Journal Image Processing, IEEE Transactionson, Volume:21, Issue: 1, 2012.

[2] T. Kobayashi and N. Otsu, “Histograms of oriented gradients for human detection, ”, ,National Institute of Advanced Industrial Science and Technology, 2008. 
[3] N. Dalal and B. Triggs, "Smile detection by boosting pixel differences,", International Conference on Computer Vision and Pattern Recognition, 2005.

[4] I Wayan Suartika E. P, Arya Yudhi Wijaya, dan Rully Soelaiman, "Klasifikasi Citra Menggunakan Convolutional Neural Network”, Caltech 101,2016

[5] Afrizal Zein, "Menggabungkan Dua Wajah Dengan Metoda Ensemble Regression Trees Menggunakan Pustaka Dlib Dan Opencv Python”, Jurnal ESIT STMIK ERESHA, 2018.

[6] Afrizal Zein, "Pendeteksian Kantuk Secara Real Time Menggunakan Pustaka Opencv Dan Dlib Python”, Sainstech: Jurnal Penelitian dan Pengkajian Sains, 2018

[7] Afrizal Zein, "Pendeteksian Multi Wajah Dan Recognition Secara Real Time Menggunakan Metoda Principal Component Analysis (Pca) Dan Eigenface”, Jurnal ESIT STMIK ERESHA, 2018.

[8] Afrizal Zein, "Manipulasi Gambar Menggunakan Jaringan Adversarial Siklus-Konsisten”, Jurnal Penelitian dan Pengkajian Sains, 2018.

[9] S. Baluja and H. A. Rowley, "Boosting sex identification performance”, Journal Image Int. J. Comput. Vision, 71(1):111-119, 2007. 